\title{
Differential Recognition of a Protective Filarial Antigen by Antibodies from Humans with Bancroftian Filariasis
}

\author{
James W. Kazura, Helen Cicirello, and Karen Forsyth* \\ Division of Geographic Medicine, Department of Medicine, Case Western Reserve University and University Hospitals, Cleveland, Ohio, \\ 44106; and *Papua New Guinea Institute of Medicine Research, Madang and Goroka, Papua New Guinea
}

\begin{abstract}
The objectives of this study were to identify filarial antigens which induce enhanced clearance of circulating microfilariae and to establish if human antibody reactivity with these molecules correlates with the apparent parasite burdens of residents of an endemic area of Bancroftian filariasis. Mice immunized with an extract of Brugia malayi microfilariae develop IgG antibodies to four major filarial antigens with an apparent molecular weight $\left(M_{\mathrm{r}}\right)$ of $\sim 112,000,60,000,45,000$, and 25,000. Animals immunized with gel slices containing the $\sim 25,000-M_{r}$ antigen are resistant to intravenous challenge with live microfilariae (7898\% reduction in parasitemia vs. controls, $P<0.01)$. A group of 22 amicrofilaremic humans had a significantly higher ( $P$ $<0.025$ ) mean antibody titer to the $M_{\mathrm{r}} 25,000-M_{\mathrm{r}}$ antigen (1: 424) than 16 microfilaremic individuals (1:95). There were no significant differences between the two groups in antibody titers to filarial antigens of $M_{\mathrm{r}} \sim 112,000,60,000$, and $45,000 M_{\mathrm{r}}$. These data suggest that a high degree of reactivity to the 25,000 $M_{r}$ antigen in humans with lymphatic filariasis correlates with a parasitologic status that is least conducive to transmission of infection.
\end{abstract}

\section{Introduction}

More than 90 million people inhabiting tropical areas of the world are infected with the helminths Wuchereria bancrofti and Brugia malayi (1). Infection of the human host by third-stage larvae $\left(\mathrm{L}_{3}\right)^{1}$ is initiated through the bites of several types of mosquitoes, including Anopheles, Aedes, Culex, and Mansonia species. The larvae mature within several months into lymphaticdwelling adult parasites which release microfilariae (mf) that can be detected in the bloodstream. The level of blood-borne $\mathrm{mf}$ is crucial to continued transmission of infection, as this parasite stage is ingested by mosquitoes during their blood meals and eventually develops into infective $L_{3}$ within the insect vector. Residents of endemic areas exhibit a wide variety of cellular and

This work was presented in part at the National Meeting of the American Federation of Clinical Research, Washington, D. C., May 1985; and was published in abstract form, 1985. Clin. Res. 33:406A. 1986

Received for publication 15 May 1985 and in revised form 10 February

1. Abbreviations used in this paper: ELISA, enzyme-linked immunosorbent assay; $\mathrm{L}_{3}$, infective larvae; $\mathrm{mf}$, microfilariae; PAGE, polyacrylamide gel electrophoresis; PBS/T, PBS containing $0.05 \%$ Tween 20; pI, isoelectric point.

J. Clin. Invest.

(c) The American Society for Clinical Investigation, Inc. 0021-9738/86/06/1985/08 $\$ 1.00$

Volume 77, June 1986, 1985-1992 humoral immune reactions to filarial antigens, ranging from an apparent lack of lymphocyte proliferative responsiveness to a marked degree of lymphoid reactivity and high levels of serum anti-mf antibodies (2-4). These differences in immune reactivity correlate, in general, with the level of microfilaremia in the human host $(5,6)$. Clinically, a variable proportion of infected individuals may show no disease manifestations. At the other extreme, chronic lymphatic obstruction with elephantiasis may be demonstrated in $>30 \%$ of adults living in endemic areas (7).

Strategies to control the spread of filariasis have included administration of antifilarial drugs and the decrease of the vector population with insecticides. As these measures have had only limited success in most endemic areas, immunologic approaches such as vaccines have been proposed. A moderate degree of resistance to infection (manifest by reductions in adult worm load and number of circulating $\mathrm{mf}$ ) can be elicited by administration of attenuated Brugia spp to dogs and monkeys $(8,9)$. Other models of animal filariasis also indicate that protective responses can be induced by exposure to live or irradiated organisms $(10,11)$. The specific protective antigens contained in these complex parasite preparations have not been biochemically defined or immunologically characterized in experimental animals or humans with filariasis. Utilizing jirds (rodent Mongolian gerbils; Meriones unguiculatus) subcutaneously challenged with $\mathrm{L}_{3}$, the natural route of infection in humans, we have recently shown that administration of a crude extract of $B$. malayi mf induces a $50 \%$ reduction in adult worm load and $>80 \%$ decrease in the intensity of microfilaremia compared with control animals (12). This moderate degree of resistance was associated with the development of jird antibodies to major $\mathrm{mf}$ antigens having apparent molecular weights $\left(M_{\mathrm{r}}\right)$ of $\sim 150,000,75,000,42,000$, and 25,000; several of these antigens were also detected in extracts of immature and mature adult filariae. Immunization of mice with the same antigen preparation also decreased the number of blood-borne $\mathrm{mf}$ in these experimental hosts by an antibodydependent mechanism (13). The present study was designed to identify the specific component(s) of the parasite preparation that induce a reduction in microfilaremia and to examine the antibody response to these antigens in clinically and parasitologically characterized groups of humans with $W$. bancrofti infection. Our results indicate that a mf antigen of $\sim 25,000 M_{\mathrm{r}}$ induces a significantly higher rate of clearance of microfilaremia in mice compared with the three other major antigens of $M_{\mathrm{r}}$ $112,000,60,000$, and $45,000 M_{\mathrm{r}}$. In humans, the serum antibody titer to the $25,000-M_{\mathrm{r}}$ antigen is significantly higher in amicrofilaremic individuals with low Gib 13 antigen indices (an independent measure of parasite load) than in microfilaremic subjects matched for age and disease status. In contrast, there were no differences between these two groups of infected subjects in antibody titers to the $112,000,60,000$, and $45,000-M_{\mathrm{r}} \mathrm{mf}$ antigens. These data suggest that a high level of antibody reactivity to antigens with an $M_{\mathrm{r}}$ of $\sim 25,000$ in human populations with 
lymphatic filariasis is associated with a parasitologic status that is least conducive to continued transmission of infection.

\section{Methods}

Antigen extracts. Jirds infected intraperitoneally with $\mathrm{L}_{3}$ of $B$. malayi were obtained from J. McCall, University of Georgia, Athens (National Institutes of Health Contract No. 73262). Mf were collected by lavage of the peritoneal cavities of 12-20-wk-infected jirds. The organisms were washed four times with phosphate-buffered saline (PBS, pH 7.0), frozen, and lyophilized. Soluble material was extracted into PBS at $4^{\circ} \mathrm{C}$ for 24 $\mathrm{h}$ and centrifuged at $20,000 \mathrm{~g}$ for $30 \mathrm{~min}$ (13); the protein concentration of the resulting supernatant was then determined (14). In some experiments, parasites were homogenized and proteins solubilized in the presence of the protease inhibitors $2 \mathrm{mM}$ phenylmethylsulfonyl fluoride, 2 $\mathrm{mM}$ tosyl-lysine chloromethyl ketone, and $2 \mathrm{mM}$ iodoacetamide (Sigma Chemical Co., St. Louis, MO). $\mathrm{L}_{3}$ were dissected from Aedes aegypti (performed at TRS Laboratories, Athens, GA), washed, sonicated, and proteins were extracted into PBS containing $0.1 \%$ Triton X 100 (Sigma Chemical Co.) (15). Immature ( $<4 \mathrm{wk}$ after the $\mathrm{L}_{3}$ stage) and mature adult $B$. malayi (males and females) were obtained from the peritoneal cavities of jirds, and extracts prepared as described for $\mathrm{mf}$.

Sources and measurements of anti-filarial antibodies. Serum containing IgG antibodies capable of conferring protection against the $\mathrm{mf}$ stage of B. malayi was obtained from 18-20-g female CF1 mice (Carworth Farms, New City, NY) injected subcutaneously with $10 \mu \mathrm{g}$ mf antigen extract 2 and 4 wk earlier (13). Adult female New Zealand white rabbits were immunized biweekly with $100 \mu \mathrm{g} \mathrm{mf}$ antigen extract in complete Freund's adjuvant (Gibco, Grand Island, NY); serum was obtained 2 wk after the last of three immunizations. Sera of $W$. bancrofti-infected humans were collected from a study population in Papua New Guinea, as described below. Six Papua New Guineans who live in a region of the country where filariasis is not transmitted served as control serum donors.

Antibodies against $B$. malayi $\mathrm{mf}$ in sera of immunized mice and rabbits were measured by enzyme-linked immunosorbent assay (ELISA) (16). Mf antigen extract $(1.0 \mu \mathrm{g}$ in $0.9 \% \mathrm{NaCl})$ was adsorbed to microtiter wells (Becton-Dickinson \& Co., Oxnard, CA) and washed twice with PBS containing 0.05\% Tween 20 (Sigma Chemical Co.) (PBS/T). Remaining sites in the plastic wells reactive with protein were blocked by addition of PBS containing 5\% bovine serum albumin (BSA) (Sigma Chemical $\mathrm{Co}$.) and incubation continued for $1 \mathrm{~h}$ at $37^{\circ} \mathrm{C}$. After washing the wells with PBS/T, we added $90 \mu \mathrm{l}$ of serial fivefold dilutions of immune or normal mouse (or rabbit) serum in PBS to triplicate wells and incubated for $3 \mathrm{~h}$ at $37^{\circ} \mathrm{C}$. The serum was then aspirated, wells were washed with $\mathrm{PBS} / \mathrm{T}$, and $80 \mu \mathrm{l}$ of a 1:3,000 dilution of alkaline phosphatase conjugated anti-mouse or anti-rabbit IgG (Cappel Laboratories, Cochranville, PA) added. After incubation overnight at room temperature, the anti-IgG was aspirated and the amount of enzyme-linked IgG bound was assayed by its reaction with $p$-nitrophenylphosphate (Sigma Chemical Co.) (16). The end titer of anti-mf antibodies was designated as the highest dilution of immune serum which resulted in a mean absorbance at least two standard deviations greater than that of a similar dilution of control serum from unimmunized animals.

A solid-phase radioimmunoassay was used to measure anti-mf antibodies in human sera. Mf antigen extract $(0.5 \mu \mathrm{g})$ was adsorbed to Immunolon 1 microtiter wells (Dynatech Laboratories, Alexandria, VA) and excess reactive sites blocked with 5\% BSA. Serum of each filariasis subject or a pool of six controls was serially diluted in PBS/T containing $5 \%$ normal rabbit serum and $90 \mu \mathrm{l}$ placed in triplicate wells for $3 \mathrm{~h}$ at $37^{\circ} \mathrm{C}$. After washing three times with PBS/T, $200,000 \mathrm{cpm}{ }^{125}$ I-labeled goat anti-human IgG (Cappel Laboratories) diluted in PBS/T with 5\% normal rabbit serum was added. The anti-IgG was radioiodinated with carrier-free ${ }^{125} \mathrm{I}-\mathrm{Na}$ (specific activity, 13-17 mci/ $\mu \mathrm{g}$; New England Nuclear, Boston, MA) and Iodobeads (Pierce Chemical Co., Rockford, IL) according to the manufacturer's specifications. Unbound ${ }^{125}$ I was separated from protein by passage of the preparation over a G-25 Sephadex column (Pharmacia Fine Chemicals, Piscataway, NJ) with PBS as eluant. After incubation of the ${ }^{125} \mathrm{I}$-anti-IgG in the wells overnight at room temperature, the contents were aspirated, and the wells were washed three times with PBS/T. Bound ${ }^{125}$ I was determined by gamma spectrometry; the end titer of human anti-mf antibodies was determined as described above for the ELISA.

Chemical and immunochemical characterization of filarial antigens. Sodium dodecyl sulfate-polyacrylamide gel electrophoresis (SDS-PAGE) was used to separate proteins contained in extracts of $\mathrm{mf}, \mathrm{L}_{3}$, immature, or mature adult $B$. malayi. Studies were done with $10 \%$ polyacrylamide and in the presence of 2-mercaptoethanol (17). Chemicals were purchased from Bio-Rad Laboratories, Richmond, CA. Two-dimensional PAGE was performed by a modification of the technique described by $O$ 'Farrell and O'Farrell (18).

The Western blot technique was used to identify filarial antigens that react with a specific set of antibodies $(19,20)$. Nitrocellulose paper (Schleicher and Schuell, Keene, NH) containing mf extracts $(30 \mu \mathrm{g})$ transferred from gels was washed first with PBS containing 5\% nonfat dry milk (Carnation Co., Los Angeles, CA) to block nonspecific protein binding (21). It was then immersed for $3 \mathrm{~h}$ at room temperature in control or immune mouse or rabbit serum diluted 1:20 and 1:50, respectively, in PBS with $5 \%$ milk. Bound antibodies were detected after washing of the paper and submersion in a solution containing $5 \times 10^{5}$ $\mathrm{cpm} / \mathrm{ml}^{125} \mathrm{I}$-labeled anti-mouse IgG (Cappel Laboratories) or ${ }^{125} \mathrm{I}$-protein A (Pharmacia Fine Chemicals) (for detection of rabbit antibodies) followed by radioautography. Preliminary experiments to assess binding of antibodies to jird proteins contained in mf extracts showed that a single protein of $67,000 M_{\mathrm{r}}$ contained in normal jird serum was detectable with sera of immunized mice and rabbits. Sera of control animals showed no reactivity with $30 \mu \mathrm{g}$ of transblotted jird serum proteins.

To examine the stage-specificity of anti-mf antibodies, extracts of $\mathrm{L}_{3}$ $(100 \mu \mathrm{g})$, immature adult and mature adult worms (60 $\mu \mathrm{g}$ each) were subjected to SDS-PAGE, transblotted, and probed with a 1:20 dilution of immune or normal mouse serum. Radioautographs were developed and the relative molecular weight of antigens from each the parasite stages were compared with those detected in $\mathrm{mf}$ extract $(60 \mu \mathrm{g})$ prepared at the same time.

Identification of protective antigens. The ability of the various $\mathrm{mf}$ antigens detected by Western blotting to induce protection in mice was compared. Gel segments ( $1 \mathrm{~mm}$ in length and $6 \mathrm{~mm}$ wide) corresponding to antigens detected by Western blots with immune mouse serum were cut out from 12 lanes loaded with $30 \mu \mathrm{g} \mathrm{mf} \mathrm{extract} \mathrm{each.} \mathrm{Gel} \mathrm{fragments}$ were then macerated with mortar and pestle and suspended in PBS to a volume of $1.2 \mathrm{ml}$. Each animal in groups of six female $18-20-\mathrm{g} \mathrm{CF} 1$ mice was injected intraperitoneally with $0.2 \mathrm{ml}$ gel suspension; controls were given material from an area of the gel not containing detectable $\mathrm{mf}$ antigens. The injections were repeated in $2 \mathrm{wk}$ and the animals challenged intravenously with $10^{5}$ live $\mathrm{mf} 2 \mathrm{wk}$ later. The level and duration of microfilaremia were determined as previously described (22).

Human study population. Antibody titers to specific $\mathrm{mf}$ antigens in a group of 22 amicrofilaremic subjects were compared with those of 16 microfilaremic humans. Sera were obtained from 38 villagers born and living in an area of Papua New Guinea endemic for bancroftian filariasis (23). Demographic information (age, sex, household), history, and pertinent physical examinations of donors were done according to World Health Organization recommendations (24) and with the prior approval of the Papua New Guinea government and Human Investigations Committee of University Hospital, Case Western Reserve University. The level of microfilaremia was determined by the nuclepore filtration technique from a 4-ml sample of blood drawn between 2,200 and 2,400 h (25). The level of circulating Gib 13 antigen was used to estimate the relative load of adult worms in the two study groups (26-28). Immulon 1 wells (Dynatech Laboratories) were coated with $50 \mu \mathrm{l}(10 \mathrm{mg} / \mathrm{ml})$ of a $50 \% \mathrm{NH}_{4} \mathrm{SO}_{4}$ precipitate of Gib 13 ascites fluid (kindly provided by Dr. G. Mitchell, Walter and Eliza Hall Institute, Melbourne, Australia), redissolved in PBS, and the assay was performed with a 1:2 dilution of serum as described by Forsyth et al. (28). Detection of the level of Gib 13 epitope in serum was expressed as an antigen index (AI) using the formula: $\mathrm{AI}=\mathrm{cpm}$ bound with test serum/mean $\mathrm{cpm}$ bound with pool 
of five control sera. An AI of $\geq 2$ was considered to indicate the presence of adult parasites (28).

To examine whether the amount of Gib 13 antigen detected in our assay might be quantitatively related to the adult worm burden, increasing numbers of immature or mature adult male or female $B$. malayi were incubated in vitro and the amount of $\mathrm{Gib} 13$ released into the medium measured. 10, 30, and 60 living immature adult female or male $B$. malayi (removed from the peritoneal cavities of jirds $1 \mathrm{~d}$ previously) were incubated for $22 \mathrm{~h}$ in $2 \mathrm{ml} \mathrm{RPMI} 1640$ (Gibco) containing $100 \mathrm{U}$ penicillin and $100 \mu \mathrm{g}$ streptomycin per $\mathrm{ml}$ at $37^{\circ} \mathrm{C}$ in $5 \% \mathrm{CO}_{2}$ and air. Similar incubations were done with 10 and 40 sexually mature adult male and

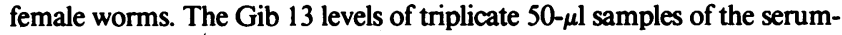
free supernatants and control medium not exposed to live parasites were then measured and the $\mathrm{AI}$ calculated as described above. Worm viability after $22 \mathrm{~h}$ incubation was $100 \%$, as judged by motility at $37^{\circ} \mathrm{C}$.

Human antibodies to $m f$ antigens. In studies with human sera, the antibody titers to microfilarial antigens of specific relative molecular weight were measured and compared. Multiple strips of nitrocellulose paper containing equivalent amounts of transferred mf extract ( $30 \mu \mathrm{g}$ applied to each gel lane) were prepared. 2-mm lengths of paper containing the antigen of interest (located by the calculated $R_{\mathrm{f}}$ value, i.e., protein migration distance divided by the dye front distance) were then cut out and duplicate samples placed in $2 \mathrm{ml}$ of immune or control human serum samples diluted $1: 100$ to $1: 10,000$ in PBS with 5\% milk. After 3$h$ incubation at $25^{\circ} \mathrm{C}$, the diluted sera were removed, the paper was washed three times with excess PBS/5\% milk, and bound antibodies were detected by immersion in $5 \times 10^{5} \mathrm{cpm}{ }^{125}$ I-protein A per milliliter for $2 \mathrm{~h}$. Individual samples of paper with attached antigen and associated antibodies were then washed extensively in PBS and radioactivity measured by gamma spectrometry (29-31). The antibody titer to a specific relative molecular weight parasite antigen was defined as the highest dilution of serum which resulted in a mean cpm of bound ${ }^{125} \mathrm{I}$-protein $A \geq$ two standard deviations above the mean value for similar dilutions of six control sera. In preliminary studies using a pool of sera from six individuals with bancroftian filariasis, it was established that there was a linear relationship between $\mathrm{cpm}{ }^{125} \mathrm{I}$-protein $\mathrm{A}$ bound to regions of the nitrocellulose paper corresponding to $\mathrm{mf}$ antigens of $112,000,60,000$, 45,000 , and $25,000 M_{\mathrm{r}}$ and the $\log _{10}$ of serum dilutions ranging from $1: 100$ to $1: 10,000$. Similar studies with pooled control serum led to lower levels of protein A binding $(<300 \mathrm{cpm})$ that did not vary with the serum dilution.

Additional experiments were performed to examine whether live $\mathrm{mf}$ removed specific anti-mf antibodies from human sera. Individual serum samples $(100 \mu \mathrm{l})$ from four amicrofilaremic residents of the endemic area were incubated with $10^{3}$ live $B$. malayi $\mathrm{mf}$ for $1 \mathrm{~h}$ at $37^{\circ} \mathrm{C}$. The organisms were then removed by sedimentation and the antibody titer of the absorbed sample was measured and compared with results using a control aliquot of the same person's serum not exposed to $\mathrm{mf}$.

Statistics. Student's $t$ test was used to assess the significance of difference among various groups.

\section{Results}

Immunological identification of filarial antigens. Mice or rabbits immunized with $\mathrm{mf}$ extract developed serum anti-mf antibodies with an end titer of 1:5,000 by ELISA (results of testing eight different batches of sera). In 10 separate experiments, sera of both animal species contained IgG antibodies that bound consistently to four major $\mathrm{mf}$ antigens of $112,000,60,000,45,000$, and $25,000 M_{\mathrm{r}}$ (Fig. 1, $A$ and $B$ ). In contrast, sera of control mice and rabbits did not react with transblotted $\mathrm{mf}$ extract (Fig. $1, C$ and $D$ ). There was no difference in these results when the $\mathrm{mf}$ extract was prepared in the presence or absence of protease inhibitors. Two-dimensional SDS-PAGE of $\mathrm{mf}$ extract showed multiple proteins with isoelectric point (pI) 4.10-6.05 and $<20,000->150,000 M_{\mathrm{r}}$. When this material was transferred to

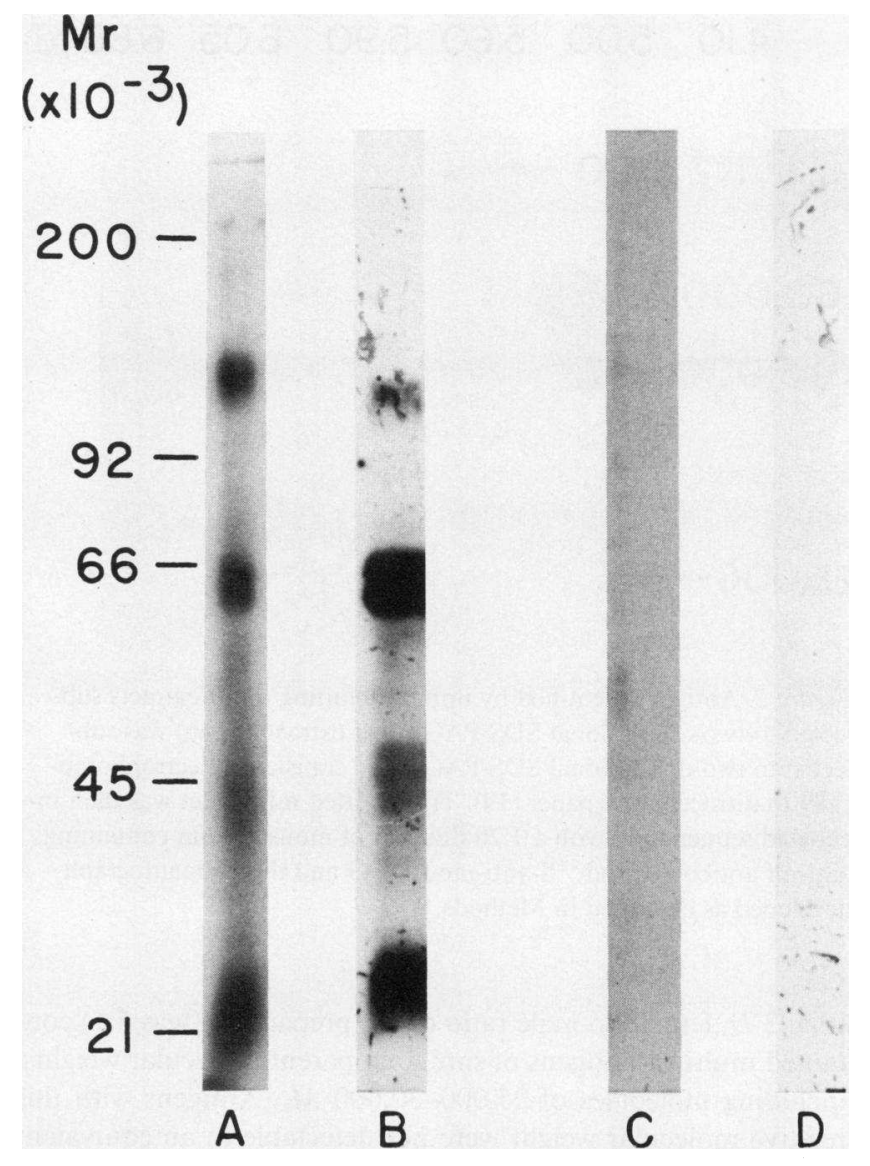

Figure 1. Microfilarial antigens recognized by mouse and rabbit anti$\mathrm{mf}$ antibodies. Soluble $\mathrm{mf}$ extracts ( $30 \mu \mathrm{g}$ ) transblotted to nitrocellulose paper were incubated with sera of mice or rabbits immunized with mf extract (IMS and IRS, respectively) or sera of control animals (NMS and NRS). Bound antibodies were detected by incubation with ${ }^{125} \mathrm{I}$-anti-mouse IgG or ${ }^{125} \mathrm{I}$-protein $\mathrm{A}$ and radioautography, as described in Methods (20-22). Lane $A, 1: 20$ dilution of IMS; lane $B$, 1:50 dilution of IRS; lane $C, 1: 20$ dilution of NMS; lane $D, 1: 50$ dilution of NRS.

nitrocellulose paper and assessed for its reactivity with immune mouse serum, antigens with relative molecular weights similar to those described for one-dimensional PAGE were noted. The $\mathrm{pI}$ of the $112,000-M_{\mathrm{r}}$ antigen complex was 5.60-5.80. The pIs of antigens of $60,000,45,000$, and $25,000 M_{\mathrm{r}}$ were 5.00-5.30, 5.10 , and 5.00, respectively (Fig. 2). Sera of age-matched control mice showed no reactivity with soluble mf extract transferred from the two-dimensional gel. Similar results were obtained with sera of mf-extract immunized and control rabbits.

To assess the stage-specificity of antigens detected with antimf antibodies, large amounts $(60 \mu \mathrm{g})$ of extracts of various parasite stages were subjected to SDS-PAGE, transferred to nitrocellulose paper, and incubated sequentially with a 1:20 dilution of immune or normal mouse serum and ${ }^{125} \mathrm{I}$-anti-mouse IgG. In addition, radioautographs were developed for $72 \mathrm{~h}$ rather than the usual $24 \mathrm{~h}$ to optimize detection of small amounts of antigen. Nonspecific binding of normal mouse serum to these parasite extracts was not observed. In contrast, immune mouse serum bound to four major $\mathrm{mf}$ antigens of $112,000,60,000$, 45,000 , and 25,000 $M_{\mathrm{r}}$ (similar to those described in Fig. 1) as well as molecules of 80,000-100,000 and 50,000-55,000 $M_{\mathrm{r}}$ (Fig. $3 \mathrm{~A}$ ). Extracts of $\mathrm{L}_{3}$ (Fig. $3 \mathrm{~B}$ ) and sexually mature adult worms 


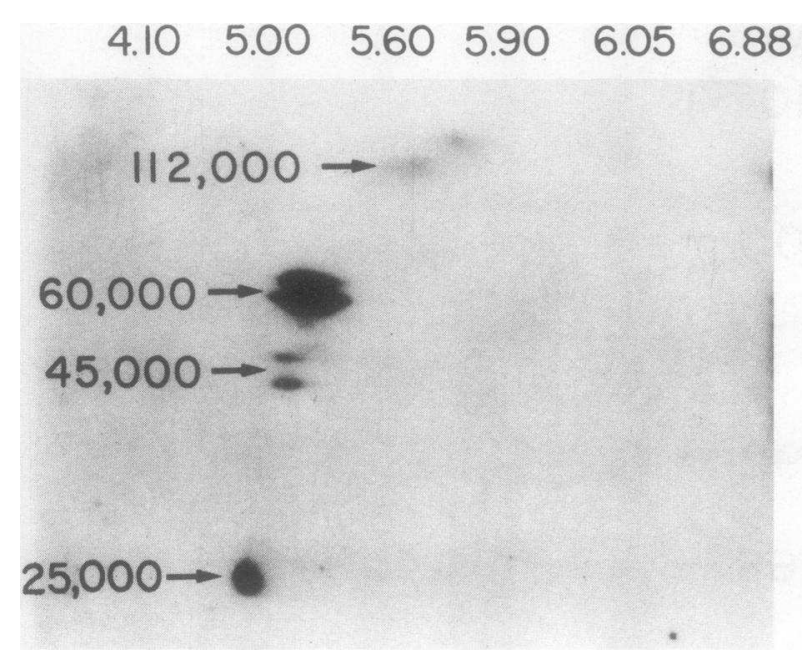

Figure 2. Antigens identified by immunoblotting of $\mathrm{mf}$ extracts subjected to two-dimensional SDS-PAGE. Mf extract ( $30 \mu \mathrm{g})$ was subjected to two-dimensional SDS-PAGE and transfered electrophoretically to nitrocellulose paper (19). Transblotted mf extract was then incubated sequentially with a 1:20 dilution of mouse serum containing anti-mf antibodies and ${ }^{125} \mathrm{I}$-anti-mouse $\mathrm{IgG}$ and the radioautograph developed as described in Methods.

(Fig. $3 D$; female to male ratio of the preparation was 5:1) contained multiple antigens of similar apparent molecular weights, including molecules of 25,000-30,000 $M_{\mathrm{r}}$. Antigens with this relative molecular weight were not detectable in an equivalent amount of proteins extracted from sexually immature adult $B$. malayi (Fig. 3 C).

Characterization of protective antigens. Two experiments to determine the ability of specific $\mathrm{mf}$ antigens to induce resistance in mice were performed. Data obtained in each were similar; results of one experiment are presented (Table I). The arithmetic and geometric mean levels of parasitemia were calculated and presented in the table. Statistical analysis was done using the arithmetic mean. Mice given control gel slices had mean levels of parasitemia of $65-69 \mathrm{mf} / 80 \mu \mathrm{l}$ blood 7-28 d after parasite challenge. This value decreased to $28 \mathrm{mf} / 80 \mu \mathrm{l}$ by $42 \mathrm{~d}$ and 0 at $70 \mathrm{~d}$. The levels of parasitemia in mice immunized with gel slices containing $\mathrm{mf}$ antigens of 112,000 or $45,000 M_{\mathrm{r}}$ were not significantly different from controls $(P>0.01)$. The group given gel material with the $60,000-M_{\mathrm{r}}$ antigen did not have a consistent decrease in microfilaremia. At $7 \mathrm{~d}$, there was a $51 \%$ reduction vs. controls $(P<0.01)$, while at $14 \mathrm{~d}$ there was no significant difference. At $28 \mathrm{~d}$, there was a $67 \%$ decrease $(P<0.01)$, whereas at $42 \mathrm{~d}$ there was no difference vs. controls (Table I). In contrast, mice given gel slices containing $\mathrm{mf}$ antigens of $25,000 M_{\mathrm{r}}$ showed a greater and consistent reduction in microfilaremia. At 7-28 d after parasite challenge, microfilaremia in this group was 78$97 \%$ lower than controls $(P<0.01)$. By $42 \mathrm{~d}$, the mean level of microfilaremia in recipients of the $25,000-M_{\mathrm{r}}$ antigen was $1 \pm 1$ parasites $/ 80 \mu \mathrm{l}$ blood ( $98 \%$ reduction compared with controls) (Table I).

Excretion/secretion of Gib 13 epitope by adult stages of $B$. malayi. In vitro studies of secretion of the Gib 13 epitope by live adult $B$. malay $i$ suggested that this assay may approximate the adult worm burden independent of the intensity of microfilaremia. 60 sexually immature adult male or female $B$. malayi released relatively large amounts of Gib 13 epitope into serum-



Figure 3. Parasite stage-specificity of antigens recognized by mouse anti-mf antibodies. Lane $A, 60 \mu \mathrm{g} \mathrm{mf}$ extract; lane $B, 100 \mu \mathrm{g}$ infective larvae $\left(\mathrm{L}_{3}\right)$ extract; lane $C, 60 \mu \mathrm{g}$ immature adult male and female worm extract; lane $D, 60 \mu \mathrm{g}$ sexually mature adult male and female extract (5:1 female to male ratio). Each preparation was subjected to SDS-PAGE and transferred to nitrocellulose paper. The paper was then incubated sequentially with a 1:20 dilution of sera of mice immunized with $\mathrm{mf}$ extract and ${ }^{125} \mathrm{I}$-anti-mouse IgG and radioautographs developed for $72 \mathrm{~h}(31)$. No reactivity was seen with control mouse serum.

free supernatant over a 22 -h period (antigen indices in $50 \mu \mathrm{l}$ of the 2 -ml culture medium were 4.7 and 2.3 , respectively) (Table II, Experiment 1). These values decreased to $\leq 1.3$ when the number of organisms was reduced to 30 or 10 . Greater amounts of the Gib 13 epitope were excreted by mature adult parasites. 40 sexually mature adult male or female worms released the Gib 13 epitope in amounts that resulted in antigen indices of 5.4 and 7.9, respectively. When the numbers of each of these organisms were reduced to 10 , the antigen indices of the supernatants remained $\geq 2.3$ (Table II, Experiment 1 ). Similar results were obtained in Experiment 2. ${ }^{125} \mathrm{I}-\mathrm{Gib} 13$ bound in the twosite radioimmunometric assay was $523 \mathrm{cpm}$ for control supernatants (RPMI 1640 incubated for $22 \mathrm{~h}$ in the absence of live parasites) and $580-4,138$ for $50-\mu l$ aliquots of $B$. malayi culture supernatants.

Characteristics of human filariasis study groups. Clinical and immunologic characteristics of the microfilaremic and amicrofilaremic residents of East Sepik Province are summarized in Table III. The mean age (32-37 yr) and disease manifestations (elephantiasis and hydroceles) attributable to chronic lymphatic obstruction were similar in both groups. The geometric mean end titers of anti-mf antibody by solid-phase radioimmunoassay were $1: 942$ and 1:2,729 in the microfilaremic and amicrofilaremic groups, respectively. Microfilaremic individuals had a sig- 
Table I. Protective Effect of Various

mf Antigens in Mice with Parasitemia*

\begin{tabular}{lllll}
\hline \multirow{2}{*}{$\begin{array}{l}M_{\mathrm{r}} \text { of } \mathrm{mf} \text { antigen } \\
\text { contained in gel } \\
\text { slice }\end{array}$} & \multicolumn{4}{l}{$\begin{array}{l}\text { Intensity of microfilaremia }(\mathrm{mf} / 80 \mu \mathrm{l} \text { blood) } \\
\text { Days after parasite challenge }\end{array}$} \\
\cline { 2 - 5 } Control gel slice & 7 & 14 & 28 & 42 \\
\hline \multirow{2}{*}{112,000} & $65 \pm 9 \ddagger$ & $69 \pm 13$ & $69 \pm 13$ & $27 \pm 4$ \\
& $(62) \S$ & $(62)$ & $(62)$ & $(24)$ \\
60,000 & $51 \pm 10$ & $41 \pm 13$ & $30 \pm 17$ & $24 \pm 12$ \\
& $(47)$ & $(41)$ & $(30)$ & $(14)$ \\
45,000 & $32 \pm 6^{\| \prime}$ & $30 \pm 8$ & $23 \pm 6^{\| \prime}$ & $18 \pm 5$ \\
& $(30)$ & $(25)$ & $(20)$ & $(15)$ \\
25,000 & $38 \pm 7$ & $43 \pm 10$ & $35 \pm 13$ & $16 \pm 4$ \\
& $(35)$ & $(39)$ & $(27)$ & $(14)$ \\
& $14 \pm 5^{\| \prime}$ & $8 \pm 3^{\| \prime}$ & $2 \pm 1^{\| \prime}$ & $1 \pm 1^{\prime \prime}$ \\
& $(10)$ & $(5)$ & $(2)$ & $(2)$
\end{tabular}

* Groups of six CFl mice were each injected intraperitoneally with gel slices containing various $M_{\mathrm{r}} \mathrm{mf}$ antigens 4 and 2 wk before intravenous challenge with $10^{5}$ live $\mathrm{mf} .80 \mu \mathrm{l}$ blood samples were obtained from the retroorbital plexus between 1,000 and $1,400 \mathrm{~h}$ and microfilariae were counted (21).

$\ddagger$ Arithmetic mean \pm standard error.

$\S$ Geometric mean.

"These values were significantly less $(P<0.01)$ than controls.

Table II. Release of Gib 13 Epitope by Immature and Mature Adult Brugia malayi Worms in Vitro*

\begin{tabular}{lcc}
\hline Parasite stage & $\begin{array}{l}\text { No. } \\
\text { incubated }\end{array}$ & $\begin{array}{l}\text { Gib 13 } \\
\text { antigen index }\end{array}$ \\
\hline Experiment 1 & & \\
Immature adult & 60 & $4.7 \ddagger$ \\
(male) & 30 & 1.2 \\
& 10 & 1.3 \\
Immature adult & 60 & 2.3 \\
(female) & 30 & 1.3 \\
& 10 & 1.1 \\
Mature adult (male) & 40 & 5.4 \\
& 10 & 2.3 \\
Mature adult & 40 & 7.9 \\
(female) & 10 & 3.4 \\
Experiment 2 & & \\
Immature adult & 40 & 2.6 \\
(male and female) & 10 & 1.5 \\
& 1 & $<1.0$ \\
Mature adult (male) & 40 & 4.1 \\
& 10 & 2.0 \\
& 1 & $<1.0$ \\
Mature adult & 40 & 5.8 \\
(female) & 10 & 5.2 \\
& 1 & $<1.0$ \\
& & \\
\hline
\end{tabular}

* The two-site radioimmunometric assay for Gib 13 epitope was performed with $50 \mu \mathrm{l}$ of serum-free control RPMI and $50 \mu \mathrm{l}$ of supernatants of duplicate preparations of $B$. malayi worms incubated at $37^{\circ} \mathrm{C}$ for $22 \mathrm{~h}$ in $5 \% \mathrm{CO}_{2}$ in air (28). The Gib 13 antigen index was calculated as described in Methods. Values exceeding 1.0 indicate net secretion/excretion of the epitope into the culture medium.

$\ddagger$ Mean of triplicate determinations for each parasite preparation. nificantly higher mean Gib 13 antigen index than amicrofilaremic subjects ( 5.6 vs. $3.1, P<0.05$ ).

Reactivity of human serum antibodies to specific filarial antigens. The serum antibody titers to $\mathrm{mf}$ antigens of 112,000 , $60,000,45,000$, and $25,000 M_{\mathrm{r}}$ in microfilaremic and amicrofilaremic subjects are shown in Table IV. There were no significant differences in the geometric mean antibody titers to mf antigens of $112,000,60,000$, and $45,000 M_{\mathrm{r}}(1: 24-1: 30$ in microfilaremic individuals vs. 1:54-1:78 in amicrofilaremic individuals, $P>0.05$ ). In contrast, the geometric mean antibody titer to the $25,000-M_{\mathrm{r}}$ antigen was significantly higher $(P<0.025)$ in the amicrofilaremic group (1:424) than the microfilaremic group (1:95). In the group without detectable circulating $\mathrm{mf}$, the serum antibody titer to this antigen was also greater than to the $112,000-, 60,000-$, and $45,000-M_{\mathrm{r}}$ antigens $(P<0.01)$. The relatively high antibody titer to the $25,000-M_{\mathrm{r}}$ antigen in amicrofilaremic subjects was not reduced by preincubation of their sera with live mf. When sera of four of these subjects were exposed to an excess number of parasites $(10,000 / \mathrm{ml})$ before measurements of binding to the $25,000-M_{\mathrm{r}}$ antigen, the antibody titers were 1:500,1:1,000,1:1,000, and 1:1,000. Values in aliquots of the same serum samples not preincubated with mf were 1:100, $1: 1,000,1: 100$, and 1:1,000, respectively.

Table III. Parasitologic, Clinical, and Immunologic Characteristics of Microfilaremic and Amicrofilaremic Human Study Groups

\begin{tabular}{|c|c|c|}
\hline & \multicolumn{2}{|l|}{ Study group } \\
\hline & Microfilaremic $(16)^{*}$ & Amicrofilaremic $(22)^{*}$ \\
\hline $\begin{array}{l}\text { Geometric mean level } \\
\text { of microfilaremia } \\
\text { (parasites/ml } \\
\text { blood) } \ddagger\end{array}$ & 423 & 0 \\
\hline \multicolumn{3}{|l|}{ Age (yr) } \\
\hline Mean & 32 & 37 \\
\hline Range & $10-59$ & $11-55$ \\
\hline Disease manifestations & $\begin{array}{c}8 \text { with elephantiasis } \\
\text { or hydroceles; } 8 \\
\text { with no disease }\end{array}$ & $\begin{array}{c}8 \text { with elephantiasis } \\
\text { or hydroceles; } 14 \\
\text { with no disease }\end{array}$ \\
\hline $\begin{array}{l}\text { Geometric mean } \\
\text { antimicrofilarial } \\
\text { antibody titer } \$\end{array}$ & $1: 942$ & $1: 2,729$ \\
\hline $\begin{array}{c}\text { Geometric mean Gib } \\
13 \text { antigen index" }\end{array}$ & $5.6 \pm 0.6 \pi$ & $3.1 \pm 0.6^{* *}$ \\
\hline
\end{tabular}

* Number of individuals per group.

$\ddagger$ A 4-ml sample of blood was drawn between 2200 and $0200 \mathrm{~h}$ and microfilaremia determined by the nuclepore filtration method $(23$, 24). When parasites on filters were too numerous to accurately count, a value of $1,000 \mathrm{mf}$ per $\mathrm{ml}$ was assigned.

$\S$ Anti-mf antibody titer to extracts of whole parasites were done by solid-phase radioimmunoassay in plastic wells as described in Methods.

"A two-site radiometric assay utilizing Gib 13 monoclonal antibody was performed (28). Values of $\geq 2.0$ are considered to be positive for filarial infection (28).

T Mean \pm standard error.

** $P<0.05$ vs. microfilaremic group. 
Table IV. Human Serum Antibody Titers

to Various Microfilarial Antigens

\begin{tabular}{|c|c|c|c|}
\hline $\begin{array}{l}M_{\mathrm{r}} \text { of filarial } \\
\text { antigen }\end{array}$ & $\begin{array}{l}\text { Microfilaremic } \\
\text { subjects }(16)^{*}\end{array}$ & $\begin{array}{l}\text { Amicrofilaremic } \\
\text { subjects (22)* }\end{array}$ & $\begin{array}{l}P \text { value (two- } \\
\text { tailed student's } \\
t \text { test) }\end{array}$ \\
\hline 112,000 & $\begin{array}{l}1.631 \pm 0.697 \ddagger \\
(1: 43) \S\end{array}$ & $\begin{array}{l}2.086 \pm 0.138 \\
(1: 122)\end{array}$ & $=0.06$ \\
\hline 60,000 & $\begin{array}{l}1.474 \pm 0.161 \\
(1: 30)\end{array}$ & $\begin{array}{l}1.891 \pm 0.186 \\
(1: 78)\end{array}$ & $>0.10$ \\
\hline 45,000 & $\begin{array}{l}1.375 \pm 0.125 \\
(1: 24)\end{array}$ & $\begin{array}{l}1.735 \pm 0.155 \\
(1: 54)\end{array}$ & $>0.10$ \\
\hline 25,000 & $\begin{array}{l}1.979 \pm 0.211 \\
(1: 95)\end{array}$ & $\begin{array}{l}2.627 \pm 0.783 \\
(1: 424)\end{array}$ & $<0.025$ \\
\hline
\end{tabular}

* No. of individuals per group.

$\ddagger$ Results are given as $-\log _{10} \pm$ standard error. Serum antibody titers were determined by solid-phase radioimmunoassay using transblotted microfilarial antigens cut from strips of nitrocellulose paper and individual serum samples diluted 1:100-1:10,000 as described in Methods. Antibody titers of $<1: 100$ were assigned a value of 1.000 for $-\log _{10}$. $\S$ Actual number for reciprocal of geometric mean antibody titer.

\section{Discussion}

Our approach to identify protective filarial molecule(s) is to select first a series of candidate antigens on the basis of their ability to prevent development and/or enhance elimination of blood-borne $\mathrm{mf}$ and adult worms in experimental animals. This was followed by documentation that antigen-induced resistance to one or several parasite stages is associated with and mediated by antibodies that recognize specific filarial antigens. The human antibody response to these specific filarial antigens was then evaluated in Papua New Guineans living in an area where Bancroftian filariasis is endemic. With the aim of establishing clinically and parasitologically meaningful correlates of this immunologic measurement, the antibody titers to these defined antigens were compared in groups of microfilaremic and amicrofilaremic individuals matched for age and disease status.

These studies indicate that four major microfilarial antigens with 25,000-112,000 $M_{\mathrm{r}}$ react with IgG antibodies in sera of mice and rabbits immunized with mf extract. Mf molecules of $108,000-112,000$ and 50,000-55,000 $M_{\mathrm{r}}$ also elicited antibody responses in occasional groups of immunized animals ( 2 of 10 groups of $\mathrm{CF} 1$ mice in the current study). Inconsistent detection of this minor group of filarial antigens may be related to variability of the immune response in outbred animals and to the greater sensitivity of the Western blot technique when larger amounts of parasite extract are subjected to SDS-PAGE (e.g., $60 \mu \mathrm{g} \mathrm{mf}$ extract in Fig. 3 vs. $30 \mu \mathrm{g} \mathrm{mf}$ extract in Fig. 1). Experiments examining the parasite stage-specificity of the various mf antigens suggest that the $112,000-M_{\mathrm{r}}$ molecule is shared by $\mathrm{L}_{3}$, immature adult worms, and sexually mature adult parasites. In contrast, the $\sim 25,000-M_{\mathrm{r}}$ antigen is detectable in $\mathrm{mf}, \mathrm{L}_{3}$, and mature adult worms but not in immature adult parasites. Competitive binding studies employing appropriate apparent molecular weight material extracted and purified from various stages of the parasite life cycle will be required to determine with certainty whether the $\sim 25,000-M_{\mathrm{r}}$ antigen (or other $\mathrm{mf}$ antigens) are present in immature adult worms and shared by female and male parasites.
Immunogenic filarial molecules with $\sim 20,000->150,000 M_{\mathrm{r}}$ have been described previously (32-37); however, their possible role in eliciting a host protective response is unknown. Immunization of jirds with the $\mathrm{mf}$ antigen preparation described here has recently been shown to induce partial resistance to subcutaneous challenge with infective larvae (12), the natural route of infection in humans. This protective response (manifest by a $>80 \%$ decrease in microfilaremia and $50 \%$ reduction in adult female worm burden) was associated with development of jird antibodies to antigens having apparent molecular weights similar to those recognized by mice and rabbits. In the present study, we compared the efficacy of the four major mf molecules in inducing resistance against microfilaremia in mice, experimental animals in which studies of antibody-dependent host clearance mechanisms directed exclusively against this stage of the parasite life cycle are possible $(13,22)$. Whereas mice immunized with gel slices containing the $112,000-, 60,000-$, or $45,000-M_{\mathrm{r}}$ antigens did not have a significantly lower level of parasitemia compared with controls, recipients of the $\sim 25,000-M_{\mathrm{r}}$ antigen showed a $78-99 \%$ reduction in microfilaremia. This $25,000-M_{\mathrm{r}}$ antigen appears to be distinct from that recently reported by Canlas and co-workers, who described a mouse $\mathrm{IgG}_{1}$ monoclonal antibody that mediated transient depression of microfilaremia in jirds and recognized $\mathrm{mf}$ surface molecules of 75,000 and 70,000 $M_{\mathrm{r}}$ (38). Differences in the results of the present report and that of Canlas et al. suggest that the method of sensitization used to produce antibodies for identification of protective antigens is selective for specific group(s) of immunogenic molecules. The monoclonal antibody which recognized antigens of 75,000 and 70,000 $M_{\mathrm{r}}$ was produced in mice injected intraperitoneally with live, intact $\mathrm{mf}$, whereas the polyvalent serum used in the present study was obtained from animals immunized with soluble extracts of the organisms. The antibody response in the former case is likely to be restricted to molecules on the surface of intact $\mathrm{mf}$ while in the latter additional antigens may be exposed by the extraction procedure.

A major goal of these studies was to examine whether human antibody reactivity to the specific filarial antigens identified in experimental animals is related to the levels of parasitemia and worm burden in residents of an endemic area. Quantification of the intensity of infection in human lymphatic filariasis has been difficult and is a subject of controversy. To define, as accurately as possible, a study population homogenous for exposure to infective larvae, we examined individuals of known age who are life-long residents of a relatively isolated area of Papua New Guinea. Migration into and out of this region of East Sepik Province is minimal. The microfilarial carrier rate in various villages ranges from 68 to $>80 \%$ (Forsyth, K. P., and J. W. Kazura, unpublished data; and 23). All individuals included in the study showed evidence of present or past exposure to lymphatic filariae. Their serum anti-mf antibody titers by solid-phase radioimmunoassay ranged from 1:250 to $1: 10,000$ compared with titers of less than 1:50 for Papua New Guineans who live in areas where Bancroftian filariasis is not transmitted. Age- and disease-matched study subjects were categorized into two groups according to the level of microfilaremia, currently the only direct method of quantifying parasite burdens in humans. To maximize the reliability of distinguishing truly microfilaremic from amicrofilaremic subjects, larger than the usual diagnostic blood samples $(4 \mathrm{ml})$ were drawn at the peak of parasitemia and were filtered by the nuclepore technique (25). As an additional indirect measure of parasitologic status, the level of circulating Gib 13 
antigen was quantified in a monoclonal antibody-based assay. The Gib 13 antibody is directed against an epitope contained in egg antigens of the filarial parasite Onchocerca gibsoni (26). Increased amounts of cross-reacting antigens are present in the sera of $W$. bancrofti-infected subjects $(27,28)$. In the current study, the mean Gib 13 level was significantly higher $(P<0.05)$ in microfilaremic subjects than in age- and disease-matched amicrofilaremic individuals. These data suggest that adult worm burdens may be greater in the group with parasitemia than in subjects without detectable circulating parasites. The use of the Gib 13 assay as an indirect index of total adult worm burden was supported by results of our in vitro studies of epitope release. It was found that the epitope is released by immature and mature adult filariae of both sexes and that the amount of Gib 13 detectable in culture supernatants of live organisms is directly related to the number of parasites present. Investigations of in vivo metabolism of the Gib 13 epitope and the possible effects of immunologic (e.g., immune complex formation) and nonimmunologic factors (e.g., vascular distribution) on its detection in serum of experimentally infected hosts will be necessary, however, to confirm the utility of this serologic test in measurements of adult worm load. Direct examination and enumeration of adult worm burdens in humans is precluded by the inaccessibility of the parasites in the lymphatics.

We finally determined whether there was a correlation between the titer of human antibodies to the various apparent molecular weight antigens identified in the protection experiments and the parasitologic status of the individuals in the filariasis study population. There were no differences in the geometric mean antibody titers to filarial antigens of $112,000,60,000$, or $45,000 M_{\mathrm{r}}$ for individuals with high levels of parasitemia (mean of 423 parasites per milliliter blood) versus those without circulating $\mathrm{mf}$. In contrast, the mean antibody titer to the $\mathrm{mf}$ antigen of $25,000 M_{\mathrm{r}}$ was significantly greater $(P<0.025)$ in the amicrofilaremic group than in the microfilaremic subjects. The relatively high antibody titer to the $25,000 M_{\mathrm{r}}$ antigen in the amicrofilaremic subjects was not due to a lack of absorption of antibody by circulating parasites, as preincubation of these sera with live $\mathrm{mf}$ failed to reduce the level of antibody binding. These data, in conjunction with in vivo protection experiments in mice, suggest that antibody responses to the $25,000-M_{\mathrm{r}}$ antigen are an important determinant of host clearance of circulating $\mathrm{mf}$. The reasons for the lower antibody titers to this specific antigen in the microfilaremic subjects are not known. Immunoregulatory processes that develop in the course of chronic infection, such as suppression of $\mathrm{T}$ and $\mathrm{B}$ cell responses to filarial antigens and development of immune complexes may, in part, be responsible $(2-4,39)$. In addition, it is possible that the isotype of antifilarial antibodies is affected (e.g., switch from IgG to IgE) by the level of parasitemia and repeated sensitization to filarial antigens (40-42). Since serum studies do not distinguish between a lack of lymphoid cells that produce antibodies and removal of antibodies by antigens released into the bloodstream by $\mathrm{mf}$ destroyed in vivo, enumeration of antigen-specific plaque-forming cells and their precursors will be an important step in evaluating further the possible utility of the $25,000-M_{\mathrm{r}}$ or other antigens for a vaccine against human filariasis.

\section{Acknowledgments}

This work was supported by grants from U. S. Public Health Services (No. AI 15351), World Health Organization (TDR-FIL), and Rockefeller
Foundation (Career Development Award to Dr. Kazura). The authors thank Adel A. F. Mahmoud for critical comments and Barbara Jackson for secretarial assistance.

\section{References}

1. World Health Organization Expert Committee on Filariasis. 1984. WHO (World Health Organization) Tech. Rep. Ser. No. 702.

2. Piessens, W. F., P. B. McGreevy, P. W. Piessens, M. McGreevy, I. Koiman, J. S. Saroso, and D. T. Dennis. 1980. Immune responses in human infections with Brugia malayi. Specific cellular unresponsiveness to filarial antigens. J. Clin. Invest. 65:172-179.

3. Piessens, W. F., F. Partono, S. L. Hoffman, S. Ratiwayanto, P. W. Piessens, J. R. Palmieri, I. Koiman, D. T. Dennis, and W. P. Carney. 1982. Antigen-specific suppressor $\mathrm{T}$ lymphocytes in human lymphatic filariasis. $N$. Engl. J. Med. 307:144-148.

4. Ottesen, E. A., P. F. Weller, and L. Heck. 1977. Specific cellular unresponsiveness in human filariasis. Immunology. 33:413-421.

5. McGreevy, P. B., S. Ratiwayanto, S. Tuti, M. M. McGreevy, and D. T. Dennis. 1980. Brugia malayi: relationship between anti-sheath antibodies and amicrofilaremia in natives living in an endemic areas of South Kalimantan, Borneo. Am. J. Trop. Med. Hyg. 29:553-562.

6. Piessens, W. F., and F. Partono. 1980. Host-vector-parasite relationships in human filariasis. Semin. Infect. Dis. 3:131-152.

7. Ottesen, E. A. 1980. Immunology of lymphatic filariasis in man. Springer Semin. Immunopathol. 2:373-385.

8. Ah, H. S., J. W. McCall, and P. E. Thompson. 1974. Vaccination against Brugia malayi infections in dogs. Proc. Third Int. Congr. Parasitol. 3:1236-1237. (Abstr.)

9. Wong, M. M., H. J. Fredericks, and C. P. Ramachandran. 1969. Studies on immunization against Brugia malayi in the rhesus monkey. Bull. W. H. O. 40:493-501.

10. Oothuman, P., D. A. Denham, P. B. McGreevy, G. S. Nelson, and R. Rogers. 1979. Successful vaccination of cats against Brugia pahangi with larvae attenuated by irradiation with $10 \mathrm{Krad}$ cobalt 60 . Parasite Immunol. (Oxf.). 1:209-216.

11. Denham, D. A. 1980. Vaccination against filarial worms using radiation-attenuated vaccines. Internat. J. Nucl. Med. Biol. 7:105-111.

12. Kazura, J. W., H. C. Cicirello, and J. McCall. 1986. Induction of protection against Brugia malayi infection in jirds by microfilarial antigens. J. Immunol. In press.

13. Kazura, J. W., and R. S. Davis. 1982. Soluble Brugia malayi microfilarial antigens protect mice against challenge by an antibodydependent mechanism. J. Immunol. 128:1792-1796.

14. Lowry, O. H., N. J. Rosebrough, A. L. Farr, and R. J. Randall. 1951. Protein measurements with the Folin phenol reagent. J. Biol. Chem. 193:265-275.

15. Ash, L. R. 1973. Chronic Brugia pahangi and Brugia malayi infections in Meriones unguiculatus. J. Parasitol. 59:442-447.

16. Engvall, E., and P. Perlmann. 1972. Enzyme-linked immunosorbent assay, ELISA. III. Quantitation of specific antibodies by enzymelabeled anti-immunoglobulin in antigen-coated tubes. J. Immunol. 109: 129-136.

17. Weber, K., and M. Osborn. 1969. The reliability of molecular weight determinations by dodecyl sulfate-polyacrylamide gel electrophoresis. J. Biol. Chem. 244:4406-4412.

18. O'Farrell, P. H., and P. Z. O'Farrell. 1977. Two-dimensional polyacrylamide gel electrophoresis. Methods Cell Biol. 16:407-420.

19. Towbin, H., T. Staehelin, and J. Gordon. 1979. Electrophoretic transfer of proteins from polyacrylamide gels to nitrocellulose sheets: procedure and some applications. Proc. Natl. Acad. Sci. USA. 76:43504354.

20. Bittner, M., P. Kupferer, and C. F. Morris. 1980. Electrophoretic transfer of proteins and nucleic acids from slab gels to diazobenzyloxymethyl cellulose or nitrocellulose sheets. Anal. Biochem. 102:459-471.

21. Johnson, D. A., J. W. Gautsch, J. R. Sportsman, and J. H. Elder. 1984. Improved technique utilizing nonfat dry milk for analysis of pro- 
teins and nucleic acids transferred to nitrocellulose. Gene Anal. Techn. 1:3-8.

22. Grove, D. I., R. S. Davis, and K. S. Warren. 1979. Brugia malayi microfilaremia in mice: a model for the study of the host response to microfilariae. Parasitology. 79:303-316.

23. Kazura, J. W., R. Spark, K. Forsyth, G. Brown, P. Heywood, P. Peters, and M. Alpers. 1984. Parasitologic and clinical features of Bancroftian filariasis in a community in East Sepik Province, Papua New Guinea. Am. J. Trop. Med. Hyg. 33:1119-1123.

24. World Health Organization Expert Committee on Filariasis. 1974. WHO (world health organization) Tech. Rep. Ser. No. 542.

25. Desowitz, R. S., and J. C. Hitchcock. 1974. Hyperendemic Bancroftian filariasis in the Kingdom of Tonga: the application of the membrane filter concentration technique to an age-stratified blood survey. Am. J. Trop. Med. Hyg. 23:877-879.

26. Forsyth, K. P., and G. F. Mitchell. 1984. Onchocerca gibsoni: increase of circulating egg antigen with chemotherapy in bovines. Exp. Parasitol. 58:41-55.

27. Dissanayake, S., K. P. Forsyth, M. M. Ismail, and G. F. Mitchell. 1984. Detection of circulating antigen in Bancroftian filariasis by using a monoclonal antibody. Am. J. Trop. Med. Hyg. 33:1130-1140.

28. Forsyth, K. P., R. Spark, J. Kazura, G. V. Brown, P. Peters, P. Heywood, S. Dissanayake, and G. F. Mitchell. 1985. A monoclonal antibody-based immunoradiometric assay for detection of circulating antigen in Bancroftian filariasis. J. Immunol. 134:1172-1177.

29. Jahn, R., W. Schiebler, and P. Greengard. 1984. A quantitative dot-immunobinding assay for proteins using nitrocellulose membrane filters. Proc. Natl. Acad. Sci. USA. 81:1684-1687.

30. Howe, J. G., and J. W. B. Hershey. 1981. A sensitive immunoblotting method for measuring protein synthesis initiation factor levels in lysates of Escherichia coli. J. Biol. Chem. 256:12836-12839.

31. Towbin, H., and J. Gordon. 1984. Immunoblotting and dot immunobinding-current status and outlook. J. Immunol. Methods. 72:313340 .

32. Boto, W. M., K. G. Powers, and D. A. Levy. 1984. Antigens of Dirofilaria immitis which are immunogenic in the canine host: detection by immunostaining of protein blots with antibodies of occult dogs. $J$. Immunol. 133:975-980.

33. Boto, W. M., R. D'Antonio, and D. A. Levy. 1984. Homologous and distinctive antigens of Onchocerca volvulus and Dirofilaria immitis: detection by an enzyme-linked immunoinhibition assay. J. Immunol. 133:981-987.

34. Tamashiro, W. K., K. G. Powers, D. A. Levy, and A. L. Scott. 1985. Quantitative and qualitative changes in the humoral response of dogs through the course of infection with Dirofilaria immitis. Am. J. Trop. Med. Hyg. 34:292-301.

35. Kaushal, N. A., R. Hussain, T. E. Nash, and E. A. Ottesen. 1982. Identification and characterization of excretory-secretory products of Brugia malayi, adult filarial parasites. J. Immunol. 129:338-343.

36. Dissanayake, S., and M. M. Ismail. 1980. Antigens of Setaria digitata: cross-reaction with surface antigens of Wuchereria bancrofti microfilariae and serum antibodies of $W$. bancroft $i$-infected subjects. Bull. W. H. O. 58:649-654.

37. Maizels, R. M., F. Partono, S. Oemijati, and B. M. Ogilvie. 1983. Antigenic analysis of Brugia timori, a filarial nematode of man: initial characterization by surface radioiodination and evaluation of diagnostic potential. Clin. Exp. Immunol. 51:269-277.

38. Canlas, M., A. Wadee, L. Lamontagne, and W. F. Piessens. 1984. A monoclonal antibody to surface antigens on microfilariae of Brugia malayi reduces microfilaremia in jirds. Am. J. Trop. Med. Hyg. 33:420424.

39. Nutman, T. B., E. A. Ottesen, A. S. Fauci, and D. J. Volkman. 1984. Parasite antigen-specific human $T$ cell lines and clones. Major histocompatibility complex restriction and B cell helper function. J. Clin. Invest. 73:1754-1762.

40. Ottesen, E. A., F. Skvaril, S. P. Tripathy, R. W. Poindexter, and R. Hussain. 1985. Prominence of $\mathrm{IgG}_{4}$ in the IgG antibody response to human filariasis. J. Immunol. 134:2707-2712.

41. Hussain, R., R. G. Hamilton, V. Kumaraswami, N. F. Adkinson, Jr., and E. A. Ottesen. 1981. IgE responses in human filariasis. I. Quantitation of filaria-specific IgE. J. Immunol. 127:1623-1629.

42. Hussain, R., and E. A. Ottesen. 1983. IgE responses in human filariasis. II. Qualitative characterization of filaria-specific IgE. J. Immunol. 131:1516-1521. 